\title{
First report of the genus Melittobia Westwood, 1848 (Hymenoptera: Eulophidae) from Vietnam, with notes on the biology of M. clavicornis (Cameron, 1908)
}

\author{
Первое сообщение о роде Melittobia Westwood, 1848 \\ (Hymenoptera: Eulophidae) из Вьетнама, с замечаниями \\ по биологии M. clavicornis (Cameron, 1908)
}

\section{Phong Huy Pham ${ }^{1,2,}$, Lam Xuan Truong, ${ }^{1,2}$, Anh Thi Tu Nguyen ${ }^{1}$

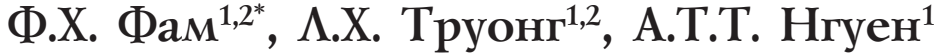

\footnotetext{
${ }^{1}$ Institute of Ecology and Biological Resources, Vietnam Academy of Science and Technology, 18 Hoang Quoc Viet, Cau Giay, Ha Noi, Vietnam.

${ }^{2}$ Graduate University of Science and Technology, Vietnam Academy of Science and Technology, 18 Hoang Quoc Viet, Cau Giay, Ha Noi, Vietnam.

* Corresponding author: phong.wasp@gmail.com
}

KEY WORDS: parasitic wasp, new host, Melittobia clavicornis, Eulophidae, Hymenoptera, Vietnam.

КЛЮЧЕВЫЕ СЛОВА: паразитические осы, новый хозяин, Melittobia clavicornis, Eulophidae, перепончатокрылые, Вьетнам.

ABSTRACT. The genus Melittobia Westwood, 1848 is reported for the first time from Vietnam based on the parasitic wasp M. clavicornis (Cameron, 1908). Chalybion bengalense (Dahlbom, 1845) and Sceliphron madraspatanum (Fabricius, 1781) are recorded as hosts of the parasitoid. Of these, the former is a new host. Some discussions on the biology of the parasitoid are included.

РЕЗЮМЕ Впервые в фауне Вьетнама отмечен род паразитоидных ос Melittobia Westwood, 1848, представленный здесь M. clavicornis (Cameron, 1908). Chalybion bengalense (Dahlbom, 1845) и Sceliphron madraspatanum (Fabricius, 1781) отмечены как хозяева этого паразитоида, первый вид в качестве нового хозяина. Обсуждаются особенности биологии паразитоида.

\section{Introduction}

Melittobia Westwood, 1848 is a genus of parasitic wasps of the family Eulophidae and is widespread in the whole world. Thirteen species are known in the genus, five of them having been recorded from the Oriental region: $M$. acasta (Waker, 1839), M. assemi Dahms, 1984, M. clavicornis (Cameron, 1908), M. hawaiiensis Perkins, 1907, and M. sosui Dahms, 1984 [Dahms, 1984; González, Matthews, 2005; Narendran, 2007; Matthews et al., 2009; Noyes, 2018]. Parasitic wasps in the genus are small, $1.0-1.5 \mathrm{~mm}$ long, gregariously developing idiobionts that primarily attack prepupae of aculeate Hymenoptera, and are normally associated with mud-dauber wasps of the genera Sceliphron Klug, 1801 and Trypoxylon Latreille, 1796 [González et al., 2004a; Matthews et al., 2009]. Freeman and Parnell [1971] showed that M. chalybii Ashmead, 1892 causes a real mortality of up to $52.3 \%$ in the developmental stages of Sceliphron assimile (Dahlbom, 1843).

While species of the genus Sceliphron build their nests with mud, those of the genus Chalybion Dahlbom, 1843 chiefly rent old nests of Sceliphron spp. [Pham, 2019a]. Species of these two genera provision their nests with paralyzed spiders of frequently the family Araneidae and overwinter on the prepupa stage [Bohart, Menke, 1976; Pham, 2019b]. Several wasps of Sceliphron have been reported as hosts of Melittobia [Rau, 1940; Sudheendrakumar, Narendran, 1984; González, Matthews, 2002; González et al., 2004a; Cusumano et al., 2012] and three species of Chalybion have been reported as hosts of Melittobia: $C$. bengalense (Dahlbom, 1845) (the host of M. assemi) [Sudheendrakumar, Narendran, 1984, 1989], C. califonicum (de Saussure, 1876) (the host of possibly M. digitata Dahms, 1984) [Obin, 1983], and C. zimmermanni Dahlbom, 1843 (the host of M. chalybii) [Ward, 1973]. In the present study, the genus Melittobia is reported for the first time from Vietnam, and $C$. bengalense is recorded as a new host of M. clavicornis.

How to cite this article: Pham H.Ph., Truong L.X., Nguyen A.T.T. 2019. First report of the genus Melittobia Westwood, 1848 (Hymenoptera: Eulophidae) from Vietnam, with notes on the biology of M. clavicornis (Cameron, 1908) // Russian Entomol. J. Vol.28. No.4. P.421-424. doi: 10.15298/rusentj.28.4.10 


\section{Materials and Methods}

Nests of both Sceliphron madraspatanum (Fabricius, 1781) and C. bengalense were mainly collected in desolated houses, sometime under bridges at several localities in North Vietnam, including Ha Noi City, Thai Binh, Quang Ninh, Hoa Binh and Son La Provinces, from 2016 to 2019. Twenty-five nests of $C$. bengalense and five nests of $S$. madraspatanum either were placed intactly in plastic jars, $10-20 \mathrm{~cm}$ high and $8-12 \mathrm{~cm}$ in diameter or were dissected and nest contents, mainly cocoons, were taken for examination under laboratory conditions. Adult wasps of $M$. clavicornis emerged from these nests were picked up and put in Ethanol (70\%) for the identification. Dahms' publication [1984] and Narendran's publication [2007] were used for the identification of the species. Photographic images were taken using a Nikon SMZ800N microscope camera.

A thorough review based on published accounts and Noyes's [2018] universal Chalcidoidea database was done to document that the identified genus and species are undoubtedly new records for the country. Voucher specimens of the parasitoid and its two hosts are deposited and preserved in the Institute of ecology and Biological Resources, Vietnam Academy of Science and Technology, Ha Noi, Vietnam and the California Academy of Sciences, 55 Music Concourse Drive, San Francisco, California, U.S.A.

\section{Results}

Two nests of $C$. bengalense were collected in a desolated house at Hong Minh Commune, Hung Ha District, Thai Binh Province on 5 February 2016 containing 11 cocoons, one taking 4 and one holding 7 . The 4 cocoon nest had only one parasitized by $M$. clavicornis with 12 adult parasitoids, all being macropterous females. The 7 cocoon nest had two parasitized by $M$. clavicornis taking 122 macropterous females. Emergence holes of the parasitoid found on these cocoons suggest that $M$. clavicornis emerges before the time of collection and apparently many adult individuals escape from them.
A nest of $C$. bengalense was picked up in a desolated stilt house at Chieu Village, Muong Thai Commune, Ham Yen District, Son La Province on 11 August 2017 containing five cocoons. Two of the five were parasitized by $M$. clavicornis and adult parasitoids emerged from them on 3 December 2017. A total of 558 adult parasitoids were counted, 6 males (Fig. 1) and 552 macropterous females. One intact nest of $S$. madraspatanum collected at the same location and day was put in a plastic jar for holding emergence adults of the species. Four adult wasps of $S$. madraspatanum emerged between 27 and 29 August. Because of omittance of observations on the cocoon, only were 27 dead macropterous females found out at the bottom of the jar on 14 December 2017, judging that the parasitoid M. clavicornis had emerged before this time and probably many adult individuals had escaped from rearing.

Two nests of S. madraspatanum were collected under a bridge at Co Nhue Ward, Bac Tu Liem District, Ha Noi City on 4 November 2017, each with 4 cocoons. Each nest contained only one parasitized cocoon. Adult parasitoids of $M$. clavicornis emerged from the two between 11 and 12 January 2018, one counting 289

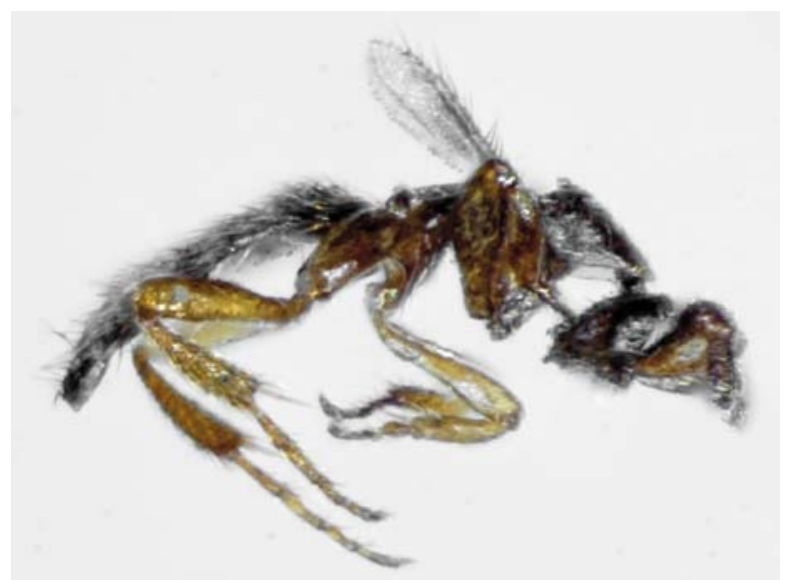

Fig. 1. Male of the parasitoid Melittobia clavicornis. Photo by Ph.H. Pham. Фам

Рис. 1. Самец паразитоида Melittobia clavicornis. Фото: Ф.Х.

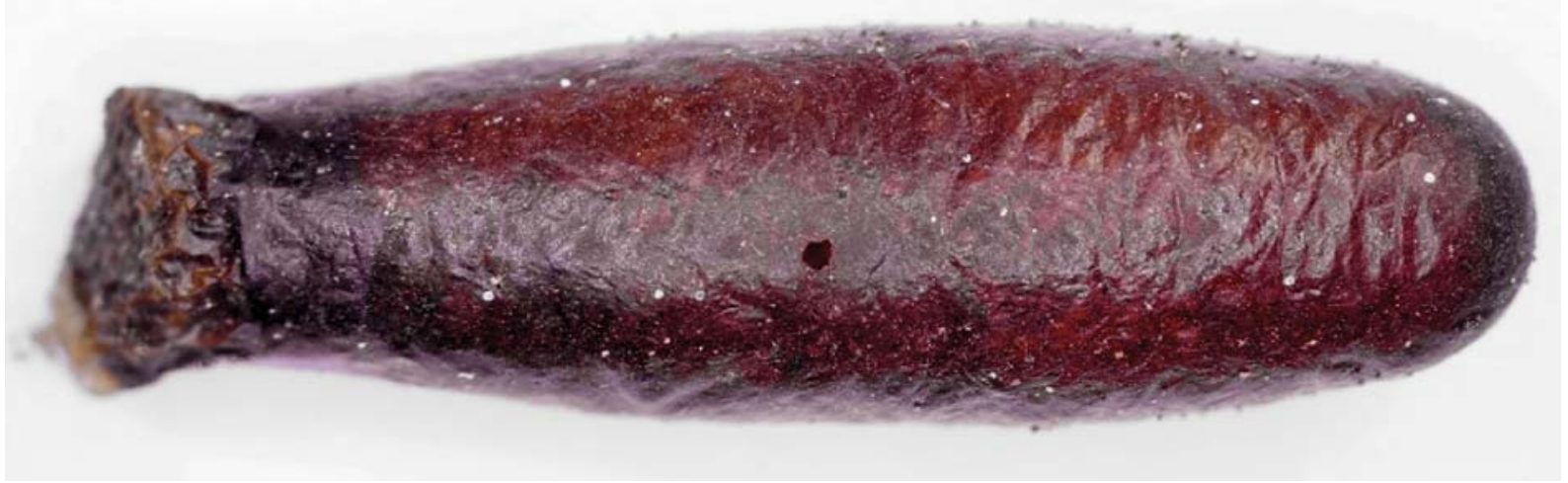

Fig. 2. Emergence hole of Melittobia clavicornis on the cocoon of Chalybion bengalense. Photo by Ph.H. Pham.

Рис. 2. Выходное отверстие Melittobia clavicornis на стенке кокона Chalybion bengalense. Фото: Ф.Х. Фам. 
adult wasps, 3 males and 286 macropterous females and another counting 334 adult wasps, 3 males and 331 macropterous females.

A nest of $S$. madraspatanum was picked up from the external wall of a human house at Hai Ha Town, Hai Ha District, Quang Ninh Province on 24 January 2018 containing 7 cocoons. One of them was parasitized by M. clavicornis. One brachypterous and 80 macropterous females were found from the cocoon on 12 February 2018 , all being died, and probably many individuals had escaped from the nest.

Twenty-two nests of $C$. bengalense were collected in a brick-built watchtower on the dike at Hong Minh Commune, Hung Ha District, Thai Binh Province between 13 and 14 February 2018. These were dissected two weeks later containing 78 cocoons. Twenty-two of 78 contained some died adult of the parasitoid, suggesting that $M$. clavicornis had emerged before the time of either dissection or collection.

A nest of $S$. madraspatanum was collected at Tan Thanh Commune, Luong Son District, Hoa Binh Province on 20 March 2019, and the nest was dissected one day later holding 6 cocoons, one being parasitized by $M$. clavicornis. At this time, 17 macropterous adult females were seen suggesting that the parasictic wasp had emerged before the time of collection and maybe many adult wasps had escaped from the cocoon.

Fifty-five cocoons of both $S$. madraspatanum and $C$. bengalense parasitized by $M$. clavicornis were measured, $15-21 \mathrm{~mm}$ and $11-18 \mathrm{~mm}$ long and 3.0-4.5 $\mathrm{mm}$ and 2.5-4.0 $\mathrm{mm}$ wide, respectively. The parasitoid $M$. clavicornis emerged from holes opened usually at about middle space of the cocoons (51 of 55) (Fig. 2), rarely at one end of the cocoons (4 of 55). The number of emergence holes on the cocoon varied from 1 to 7 , much frequently 1 (39 of 55).

\section{Discussion}

Melittobia clavicornis was described more than 100 years ago by Cameron [1908] based on specimens collected in Borneo (Kunching), Malaysia under a synonym Philopison clavicornis. The species has been recorded from Malaysia (Borneo), Sri Lanka, Hawaii, and Japan [Dahms, 1984; Matthews et al., 2009; Noyes, 2018]. In the present study, the genus Melittobia is first recorded for the eulophid wasp fauna of Vietnam based on the parasitic wasp $M$. clavicornis.

González et al. [2004b] showed 18 insect species as the hosts of $M$. clavicornis, almost being solitary wasps, and in the present study, C. bengalense, is reported as a new host of the parasitoid. Whereas $C$. bengalense is reported as the host of $M$. assemi in India by Sudheendrakumar and Narendran [1984, 1989], S. madraspatanum is reported to be the host of M. clavicornis in Japan by González et al. [2004b].

In North Vietnam, the winter lasts from November to April of the following year and the two species $S$. madraspatanum and $C$. bengalense overwinter on the prepupae stage. Almost nests of both were collected in the winter containing $M$. clavicornis, suggesting that the parasitoid attacks the prepupa stage of the two species and takes no overwintering. Many nests of the two species $S$. madraspatanum and $C$. bengalense are collected and reared in the summer, but no the parasitic wasp M. clavicornis is found. Probably the prepupa stage of the two in the winter is consistent with the parasitic action of $M$. clavicornis.

The number of adult individuals of $M$. clavicornis varies on different hosts: fewer than 200 on Trypoxylon politum Say, 1837, fewer than 60 on Anthrax sp., fewer than 40 on Sarcophaga (Neobellieria) bullata (Parker, 1916), and fewer than 200 on Trypoxylon spp. [González et al., 2004b]. In the present study, that was fewer than 300 on $C$. bengalense and about 300 on S. madraspatanum. The difference of the number of parasitic individuals on different hosts is due to food quality (nutrition) which affects to not only sexual ratio but also both macropterous and brachypterous morphs [Gonzáles, Matthews, 2002; Silva-Torres, Matthews, 2003; Cusumano et al., 2012]. The female dimorphism is a common character of the genus Melittobia and this is also reported in the case of $M$. clavicornis [Cameron, 1908; González et al., 2004b]. However, while both macropterous and brachypterous females of $M$. clavicornis are commonly found in Borneo (Malaysia) and Japan, only fairly macropterous females are found in Vietnam (only the Quang Ninh population with one brachypterous female). This remains to be cleared further.

Acknowledgements. The authors are grateful to Dr. Robert L. Zuparko, California Academy of Science, 55 Music Concourse Drive, San Francisco, California, USA for the initial identification of the species. The authors thank an anonymous reviewer for his valuable comments and suggestions on the manuscript. The present study was supported by the Vietnam Academy of Science and Technology under grant No. ĐLTE00.05/19-20.

\section{References}

Bohart R.M., Menke A.S., in collaboration with Court H.S. [sic], Parker F.D., Grissell E.E., and Levin D.P. 1976. Sphecid wasps of the world: A generic revision. Berkeley, Los Angeles, London: University of California Press. IX +695 pp., 1 color plate.

Cameron P. 1908. Descriptions of two new genera and species of reared Chalcididae from Borneo // Dtsch. Entomol. Z. Vol.5. P.559-561.

Cusumano A., González J.M., Colazza S., Vinson S.B. 2012. First report of Melittobia australica Girault in Europe and new record of M. acasta (Walker) for Italy // Zookeys. Vol.181. P.45-51.

Dahms E.C. 1984. Revision of the genus Melittobia (Chalcidoidea; Eulophidae) with the description of seven new species // Mem. Queensl. Mus. Vol.21. No.2. P.271-336.

Freeman B.E., Parnell J.R. 1973. Mortality of Sceliphron assimile Dahlbom (Sphecidae) caused by the eulophid Melittobia chalybii Ashmead // J. Anim. Ecol. Vol.42. P.779-784.

González J.M., Matthews R.W. 2002. Development and sex ratio of Melittobia australica and M. digitata (Hymenoptera: Eulophidae) on Megachile rotundata (Hymenoptera: Megachilidae) and Trypoxylon politum (Hymenoptera: Sphecidae) // Great Lakes Entomol. Vol.35. No.1. P.85-91. 
González J.M., Genaro J.A., Matthews R.W. 2004a. Species of Melittobia (Hymenoptera: Eulophidae) established in Bahamas, Costa Rica, Cuba, Hispaniola, Puerto Rico, and Trinidad // Fla. Entomol. Vol.87. No.4. P.619-620.

González J.M., Abe J., Matthews R.W. 2004b. Offspring production and development in the parasitoid wasp Melittobia clavicornis (Cameron) (Hymenoptera: Eulophidae) from Japan // Entomol. Sci. Vol.7. No.1. P.15-19.

González J.M., Matthews R.W. 2005. An annotated bibliography of Melittobia (Hymenoptera: Eulophidae) // Carib. J. Sci. Spec. Publ. Vol.8. P.1-41.

Matthews R.W., González J.M., Matthews J.R., Deyrup L.D. 2009. Biology of the parasitoid Melittobia (Hymenoptera: Eulophidae) // Annu. Rev. Entomol. Vol.54. P.251-266.

Narendran T.C. 2007. Indian chalcidoid parasitoids of the Tetrastichinae (Hymenoptera: Eulophidae) // Rec. Zool. Surv. of India. Occ. Paper No.272. 386 pp.

Noyes J.S. 2018. Universal Chalcidoidea Database. World Wide Web electronic publication. http://www. nhm.ac.uk/chalcidoids. Accessed: 25 November 2018.

Obin M.S. 1983. Behavior and nesting biology of the blue muddauber Chalybion californicum (Saussure) (Hymenoptera: Sphecidae). M.Sc. Thesis. University of Florida, Gainesville. 139 pp.

Pham Ph.H. 2019a. Notes on nest and gregarious behavior of a blue nest-renting wasp, Chalybion japonicum (Gribodo), with com- ments on commonly used name for Chalybion species (Hymenoptera: Sphecidae) // Entomologica Americana. Vol.124. No.1. P.35-38. http://doi.org/10.1664/1947-5136-124.1.35.

Pham Ph.H. 2019b. The nesting habits of Chalybion bengalense (Dahlbom) (Hymenoptera: Sphecidae)//Oriental Insects. Vol.53. No.3. P.112. https://doi.org/10.1080/00305316.2019.1624220.

Rau P. 1940. The life history of the American cockroach, Periplaneta americana Linn. (Orthop.: Blattidae) // Entomol. News. Vol.51. No.8. P.223-227.

Silva-Torres C.S.A., Matthews R.W. 2003. Development of Melittobia australica Girault and Melittobia digitata Dahms (Parker) (Hymenoptera: Eulophidae) parasitizing Neobellieria bullata (Parker) (Diptera: Sarcophagidae) puparia // Neotrop. Entomol. Vol.32. No.4. P.645-651.

Sudheendrakumar V.V., Narendran T.C. 1984. Bio-ethology of an undescribed species of Melittobia (Hymenoptera: Eulophidae) parasitic on sphecoid wasps of Malabar (Kerala) // Ind. J. Parasit. Vol.7. No.2. P.143-148.

Sudheendrakumar V.V., Narendran T.C. 1989. Biology of the immature stages of Chalybion bengalense (Dahlbom) (Hymenoptera: Sphecidae) // Entomon. Vol.14. Nos3-4. P.177-181.

Ward G.L. 1973. Melittobia chalybii Ashmead (Hymenoptera: Eulophidae) as a parasite of Chalybion zimmermanni Dahlbom (Hymenoptera: Sphecidae) // Proc. Indiana Acad. Sci. Vol.82. P.233-234. 